\title{
Impact of National Board for Technical Education Accreditation Exercise on Office Technology and Management Programme of Polytechnics in Nigeria
}

\author{
Solomon I. Agholor \\ Department of Office Technology \& Management, Delta State Polytechnic, Ozoro, Nigeria \\ Email address: \\ talktomcben@yahoo.com
}

\section{To cite this article:}

Solomon I. Agholor. Impact of National Board for Technical Education Accreditation Exercise on Office Technology and Management Programme of Polytechnics in Nigeria. International Journal of Vocational Education and Training Research.

Vol. 3, No. 2, 2017, pp. 15-20. doi: 10.11648/j.ijvetr.20170302.11

Received: October 29, 2016; Accepted: March 1, 2017; Published: June 16, 2017

\begin{abstract}
The study was designed to find out the impact of NBTE accreditation exercise on office technology and management programme of polytechnics in South-South Nigeria. Three research questions were raised to guide the study while one null hypothesis was tested at 0.05 level of significance. The study adopted descriptive survey design. The entire population of 95 office technology and management lecturers in polytechnics in South-South Nigeria where OTM programme is offered were used for the study. Data were collected for the study through the administration of validated questionnaire on the respondents. Test-retest method was used to determine the reliability of the instrument. The mean statistics was used to answer the research questions while t-test statistic was used to test the hypothesis. The result of this study revealed that NBTE accreditation exercise has positive impact on quality of personnel, adequacy of physical facilities and equipment and relevant academic contents in office technology and management programme of polytechnics in South-South Nigeria. It was therefore recommended among others that NBTE should continue to encourage qualified and experienced academic staff and adequacy of physical facilities and equipment in office technology and management programme and that an effective mechanism for verifying claims made by office technology and management programme during accreditation should be put in place.
\end{abstract}

Keywords: Impact, National Board for Technical Education, Accreditation, Office Technology and Management

\section{Introduction}

\subsection{Background to the Study}

Polytechnic education in Nigeria is one of the tertiary levels of education given after secondary education. Accordingto [1], it is a two tier programme of studies that consist of National Diploma and Higher National Diploma with one year industrial experience as one of the prerequisites for entry into the HND programme. The National Policy on Education maintained that the objectives of polytechnic education are; to provide full-time course of instructions and training in engineering, other technologies and applied sciences, business and management leading to the production of trained manpower; to provide the technical knowledge and skills necessary for occupational development in Nigeria as well as to give training and impact necessary skills for the production of skilled personnel who shall be enterprising [2]. One of the programmes run in polytechnics in Nigeria to achieve the above objectives is office technology and management.

The office technology and management programme came into existence in Nigerian polytechnics in 2004 after the review of old secretarial studies curriculum for producing office workers in Nigeria. This review was taken with the view to produce graduates who could be efficient in management roles and have the confidence and practical skills necessary for office functions. This new Office Technology and Management programme has been described as having apparent advantages because of UNESCO assistance during the review which introduced international perspectives to the curriculum and enabled it to benefit from some of the best practices around the world particularly, the office technology component which includes the 
convergence of computer, telecommunication, internet and information and communication competencies that were lacking in the various curricula for producing office workers in Nigeria. In order to attain the goals and objectives of the programme, relevant mechanisms are put in place to ensure proper standards and quality. One of such mechanism is programme accreditation by National Board for Technical Education.

National Board for Technical Education is principal arm of Federal Ministry of Education vested with power to ensure quality control in polytechnic education in Nigeria. The agency was established in 1977 and it has powers to ensure quality of process, products and services. It draws up the basic curricula, set minimum standards in staffing, curriculum, academic programmes, physical facilities and equipment, administration and leadership, and conducts programme accreditation; an instrumentality through which NBTE adjudges the adequacy or otherwise of the relevant programme quality indices.

Accreditation can be broadly defined as a process leading to the granting of approval or authority to a programme or institution after meeting set minimum standards and criteria [3]. According to [4], accreditation is an evaluation of whether an institution or a programme meets the threshold standards and qualifies for a certain status. It could also mean the process by which the quality and standard of educational institutions assessed. The accreditation exercise always follows a set of minimum standard against which programme are evaluated.

NBTE accreditation of office technology and management programme in polytechnics has assumed new significance as a result of the remarkable changes occasioned by the review of the curriculum for producing office workers in Nigeria. Almost all aspect of the programme was reviewed to reflect the current trends in information and communication technology era.The nomenclature, the curriculum, the physical facilities and equipment, the level of funding and quality of leadership required of the programme have been reviewed.

With the above changes, one would expect commensurate changes in the outcome of the programme. However, emerging indications suggests that many graduates of OTM programme find it difficult to fit perfectly into modern office and perform professionally according to expectation. Study carried out by [1] revealed that graduates of office technology and management were barely proficient in the use of office application for effective job performance in modern office. [5] and [6] found that polytechnics in Nigeria do not have sufficient facilities for teaching the practical based OTM courses which constitute almost $70 \%$ of the core departmental courses. Similarly, studies have revealed that lack of knowledge, confidence, technological competence and content to support students learning with ICT in teaching ICT in classroom is the most persistent and daunting challenges facing educational system in Nigeria.In the face of these challenges, one wonder, whatimpact NBTE accreditation exercise has on office technology and management programme with particular reference to polytechnics in South-South Nigeria.

\subsection{Statement of Problem}

Programme accreditation by NBTE is designed to ensure standard and quality in vocational and technical education programme in Nigerian polytechnics. Despite this mechanism, there are still complains about the quality of polytechnic education and graduates in Nigeria particularly office technology and management graduates.

For instance, [7] conducted a research with 30 OTM graduates in Hassan Usman Katsina Polytechnic and found out that 18 of them lacked record keeping efficiency, 21 faced problems in record keeping roles and 16 could not effectively perform I.C.T roles. The author noted further that they specialized only on word processing aspect. At times, executives complain of missing documents; delays in retrieving files/stored documents rudeness to the visitors by their secretaries, inability to compose secretaries routine correspondence, take minutes of meeting and so on [8]. Similarly, a study conducted by [8] showed that many office technology and management graduate workers (secretaries) in government ministries in Delta State, Nigeria lack competence in many office applications needed for effective work performance in modern office.

Education in Nigeria is described as one of the massive explosion in students' enrolment; increasing number of prospective new entrants in the face of inadequate and obsolete infrastructure and equipment; poor library facilities, inadequate academic staff in number and quality, low funding and examination malpractice which leads to low quality graduates [3].

In view of theseproblems, it appears the polytechnics do not seem to have adequately met the minimum academic standard set up by NBTEto ensure standard and quality control in the system. In other words, the accreditation exercise which is a mechanism for quality control seems not to have had remarkable impact on academic programmes particularly office technology and management. Hence, the need find out the impact of NBTE accreditation exercise on office technology and management programme with particular focus on personnel, facilities and academic contents.

\subsection{Purpose of the Study}

The main purpose of the study was to determine the impact ofNBTE accreditation exercise on office technology and management programme of polytechnics in South-South Nigeria. Specifically, the study sought to determine the impact of NBTE accreditation exercise on:

1) The quality of personnel in office technology and management programme of polytechnics in south-south Nigeria

2) The adequacy of physical facilities in office technology and management programme of polytechnics in southsouth Nigeria.

3) The relevance of the academic content in office 
technology and management programme of polytechnics in south-south Nigeria.

\subsection{Research Questions}

The study was guided by the following research questions

1) What is the impact NBTE accreditation exercise on the quality of personnel in office technology and management programme of polytechnics in south-south Nigeria?

2) What is the impact NBTE accreditation exercise on the adequacy of physical facilities in office technology and management programme of polytechnics in south-south Nigeria?

3) What is the impact of NBTE accreditation exercise on the relevant academic content in office technology and management programme of polytechnics in south-south Nigeria?

\subsection{Hypothesis}

$H_{0}$ : There is no statistically significant difference between the mean rating of male and female business educators on the impact of NBTE's accreditation exercise on office technology and management programme of polytechnics in south-south Nigeria.

\section{Method}

The research design used for this study is survey design to assess the impact of NBTE accreditation exercise on office technology and management programme in polytechnics in south-south Nigeria. The population of the study consists of all the 95 office technology and management lecturers in polytechnics in south-south Nigeria where office technology and management programme is run. The distribution of lecturers according to their institutions are as follows: Auchi Polytechnic, Auchi (22); Akwa Ibom State Polytechnic, Itok (9); Rivers State Polytechnic, Bori(16); Federal Polytechni, Ikenwen (13); Delta State Polytechnic, Oghara (12); Delta State Polytechnic Ozoro (12); Delta State Polytechnic Ogwashi-Uku (11) and Delta State Polytechnic Oghara (12).This information was generated from the various institutions. The entire population was used for the study since the number is small and relatively manageable, hence there was no sampling.

A 20 item questionnaire was used as instrument for the study. The research instrument has two parts - Part A and Part B. Part A contains information on the respondent's biographic data. Part B is divided into three sections in line with research questions raised for the study. The instrument was structured to elicit information from the assessment of respondents on a 4 point rating scale as follows:

$\begin{array}{lll}\text { Strongly Agreed } & \text { (SA) } & 4 \\ \text { Agreed } & \text { (A) } & 3 \\ \text { Disagreed } & \text { (D) } & 2 \\ \text { Strongly Disagreed } & \text { (SD) } & 1\end{array}$

To establish the validity of the instrument, it was given to three experts in Department of Vocational Education, University of Benin, Benin City, Edo State Nigeria. Their observations were effected on the questionnaire before final copy was written. The test-retest method was used to determine the reliability of the instrument. The questionnaire was administered to ten OTM lecturers in a polytechnic outside their area of study. After an interval of two weeks, the same instrument was administered to the set of respondents. The result was computed using Pearson Product Moment Correlation Formula which yielded a reliability coefficient of 0.86 which was high enough to consider the instrument reliable.

The questionnaire constructed was administered by the researcher to the respondents with the aid of research helpers. The researcher was able to collect some of the questionnaire on the spot while other were collected after few days. Out of a total of 95 questionnaire distributed 85 copies were returned base on which analysis for this study was done. In analyzing the data to be collected from the instrument administered, simple mean was used to analyze the responses for research question while t-test was used to test the hypothesis formulated for the study. The Decision Rule is this: Any item with a mean rating that is equal to or greater than 2.5 was considered 'Agreed' while any item with a mean rating that is less than 2.5 was considered 'Disagreed'. The null hypothesis was tested using t-test statistics at $\mathrm{p}<0.05$.

\section{Result}

The results of the study were presented in tables according to research questions while the test of hypothesis was presented in Table 4

\subsection{Research Question 1}

What is the impact of NBTE accreditation exercise on the quality of personnel in office technology and management programme of polytechnics in south-south Nigeria?

Table 1.Respondents' Mean Rating on the Impact of the NBTE Accreditation on Quality of Personnel in Polytechnics $(N=85)$.

\begin{tabular}{|c|c|c|c|}
\hline $\mathbf{S} / \mathbf{N}$ & Items & Mean & Remark \\
\hline 1 & Adequate number of academic staff & 2.60 & Agreed \\
\hline 2 & $\begin{array}{l}\text { Adequate rank mix ( } 20 \% \text { professional } \\
\text { grade, } 35 \% \text { in the senior lecturer grade } \\
\text { and } 45 \% \text { in the lecturer } 1 \text { grade and } \\
\text { below) of academic staff }\end{array}$ & 3.53 & Agreed \\
\hline 3 & Availability of qualified academic staff & 3.34 & Agreed \\
\hline 4 & Adequate experienced academic staff & 2.61 & Agreed \\
\hline 5 & Appropriate staff students ratio of $1: 30$ & 2.05 & Disagreed \\
\hline 6 & Assignment of staff advisers for students & 3.60 & Agreed \\
\hline 7 & Adequate number of non-academic staff & 3.55 & Agreed \\
\hline 8 & $\begin{array}{l}\text { Competent technical officers manning } \\
\text { the computer laboratory }\end{array}$ & 3.00 & Agreed \\
\hline 9 & $\begin{array}{l}\text { Competent representation at the } \\
\text { Academic Board }\end{array}$ & 3.20 & Agreed \\
\hline \multirow[t]{2}{*}{10} & $\begin{array}{l}\text { Staff development programme for all } \\
\text { staff }\end{array}$ & 3.00 & Agreed \\
\hline & Grand Mean & 3.05 & Agreed \\
\hline
\end{tabular}

The data in Table 1 revealed the impact of NBTE 
accreditation exercise on the quality of personnel in office technology and management programme of polytechnics in South-South Nigeria. Apart from appropriate staff students ratio of 1:30, the respondents were of the opinion that NBTE accreditation exercise has great impact on the quality of personnel in office technology and management programme in terms of adequate number of academic staff, adequate rank mix, qualified and experienced, assignment of staff advisers for students, adequate number of nonacademic staff, competent technical officers manning computer laboratory, competent representation at the Academic Board and staff development programme for all staff. The grand mean of 3.05 shows that the respondentsagreed that NBTE accreditation exercise has positive impact on the quality of personnel for office technology and management programme.

\subsection{Research Question 2}

What is the impact of NBTE accreditation exercise on the adequacy of physical facilities in office technology and management programme of polytechnics in south-south Nigeria?

Table 2. Respondents' Mean Rating on the Impact of the NBTE Accreditation Exercise on the Adequacy of Physical Facilities ( $N=85)$.

\begin{tabular}{|c|c|c|c|}
\hline $\mathbf{S} / \mathbf{N}$ & Items & Mean & Remark \\
\hline 11 & $\begin{array}{l}\text { Adequate number of departmental } \\
\text { classrooms }\end{array}$ & 3.22 & Agreed \\
\hline 12 & Spacious and well ventilated classrooms & 2.60 & Agreed \\
\hline 13 & $\begin{array}{l}\text { Adequate number of working computers in } \\
\text { the computer laboratory }\end{array}$ & 3.00 & Agreed \\
\hline 14 & $\begin{array}{l}\text { Adequate number of working typewriters in } \\
\text { the typing pool }\end{array}$ & 2.82 & Agreed \\
\hline 15 & $\begin{array}{l}\text { Adequate number of office practice } \\
\text { equipment }\end{array}$ & 3.20 & Agreed \\
\hline 16 & Wellventilated model offices & 3.61 & Agreed \\
\hline 17 & Well furnished HOD's office & 2.54 & Agreed \\
\hline 18 & Well ventilated secretary's office & 3.20 & Agreed \\
\hline 19 & Spacious office for lecturers & 2.89 & Agreed \\
\hline \multirow[t]{2}{*}{20} & $\begin{array}{l}\text { Computer system for lecturers in the } \\
\text { department }\end{array}$ & 3.12 & Agreed \\
\hline & Grand Mean & 2.92 & Agreed \\
\hline
\end{tabular}

Table 2 reveals the impact of NBTE accreditation exercise on adequacy of physical facilities in office technology and management programme. All the items in this section received mean rating greater than 2.50 . The grand mean of 3.84 is a further indication of respondent agreement to the items as theimpact of NBTE accreditation exercise on adequacy of physical facilities in office technology and management programme of polytechnics in South-South Nigeria.

\subsection{Research Question 3}

What is the impact of NBTE accreditation exercise on the relevant academic content in office technology and management programme of polytechnics in south-south Nigeria?
Table 3. Respondents' Rating on the Impact of the NBTE Accreditation Exercise on the Relevant Academic Content $(N=85)$.

\begin{tabular}{llll}
\hline S/N & Items & Mean & Remark \\
\hline 21 & $\begin{array}{l}\text { Up-to-date curriculum that meets the } \\
\text { demands of industry and society }\end{array}$ & 2.60 & Agreed \\
22 & $\begin{array}{l}\text { Periodic review of office technology and } \\
\text { management curriculum } \\
\text { Adequate ICT contents in current } \\
\text { curriculum }\end{array}$ & 3.53 & Agreed \\
& $\begin{array}{l}\text { Adequate course contents on } \\
\text { entrepreneurship education }\end{array}$ & 3.64 & Agreed \\
25 & $\begin{array}{l}\text { Compulsory 4-months SIWES for office } \\
\text { technology and management students }\end{array}$ & 3.05 & Agreed \\
26 & $\begin{array}{l}\text { Fair assessment of quizzes } \\
\text { Fair assessment of examination } \\
\text { Availability of strictly followed marking } \\
\text { scheme }\end{array}$ & 2.60 & Agreed \\
28 & $\begin{array}{l}\text { Use of appropriate methodologies in } \\
\text { supervising students projects } \\
\text { Effective external moderation of } \\
\text { examination } \\
\text { Grand Mean }\end{array}$ & 3.00 & Agreed \\
\hline
\end{tabular}

Table 3 reveals the impact of NBTE accreditation exercise on relevant academic contents in office technology and management programme. All the items in this section received mean rating greater than 2.50 . The cluster mean of 2.98 indicates that the respondents agreed that NBTE accreditation exercise has positively impacted office technology and management programme of polytechnics in South-South Nigeria in terms of on relevant academic contents.

\subsection{Testing of Hypothesis}

Table 4. The z-test Analysis of Male and Female Respondents on the Impact of NBTE Accreditation Exercise on Office Technology and Management Programme.

\begin{tabular}{lllllllll}
\hline Gender & $\mathbf{N}$ & $\mathbf{X}$ & $\mathbf{S}$ & z-cal & $\alpha$ & Df & z-crit & Remark \\
\hline Male & 32 & 3.52 & 0.28 & \multirow{2}{*}{1.41} & \multirow{2}{*}{0.05} & \multirow{2}{*}{83} & \multirow{2}{*}{1.96} & \multirow{2}{*}{ Retained } \\
Female & 53 & 3.42 & 0.34 & & & & & \\
\hline
\end{tabular}

Table 4, shows z-test analysis of responses of male and female OTM lecturers on the impact of NBTE accreditation exercise on office technology and management programme of polytechnics in South-South Nigeria with mean scores of 3.52 and 3.42 respectively. The z-calculated value of 1.41 is less than the $z$-tabulated value of 1.96 at 83 degree of freedom and 0.05 level of significance. Therefore, the null hypothesis is retained whichimplies that, there is no statistically significant difference between the mean rating of male and female OTM educators on theimpact of NBTE accreditation exercise on office technology and management programme of polytechnics in South-South Nigeria

\section{Discussion of Results}

The findings of this study showed that NBTE accreditation exercise has positive impact on the quality of personnel in office technology and management programme of polytechnic in South-South Nigeria. This result is not in line 
with the position of [9] who maintained that the observations about the quality of staff in the accreditation process are often contrived.According to them, staff are often hired or borrowed ahead of accreditation only to be fired immediately after accreditation. However, [3] has advocated that for the educational system to meet up with its expectation, both in input, process and output, there is need for the institutions to follow the laid minimum academic standard.

Again, the result in Table 2 reveals the impact of NBTE accreditation exercise on the adequacy of physical facilities in office technology and management programme. The result revealed that NBTE accreditation exercise has positive impact on office technology and management programme in terms of adequate number of departmental classrooms, spacious and well ventilated classrooms, adequate number of working typewriters and computers, adequate number of office equipment, well ventilated model office, HOD's office, lecturers' office and secretary's office as well as computer system for lecturers in the department. This result is in agreement with the view of [10] who posited that physical facilities provides effective teaching and learning in tertiary institutions. The author maintained that shortage of equipment and facilities affect the quality of teaching and learning as quality diminishes when the facilities required for the teaching and learning are inadequate or at times not available.

The result in Table 3 shows the impact of NBTE accreditation exercise on relevant academic contents in office technology and management programme. The result indicates that the respondents agreed that NBTE accreditation exercise has positively impacted office technology and management programme in South-South Nigeria in terms of on relevant academic contents. The result is supported by [11] that a good curriculum must diagnose societal needs, have sound and tested objectives, select appropriate learning content, organize the learning content, select appropriate learning experiences, organize the learning experiences and determine what to evaluate and how to evaluate it. The result also agreed with [12] who maintained that SIWES provides opportunity for student to supplement the theoretical learning with practical industrial activities in their various discipline; expose and prepare students for industrial situation they are likely to meet after graduation.

\section{Conclusions}

Based on the result of the study, it is concluded thatNBTE accreditation has positive impact on office technology and management programme of polytechnics in South-South Nigeria. When the accreditation exercise is properly carried out, it would enable the polytechnics to attain and maintain the laid down minimum academic standard which is required to achieve the goals and objectives of office technology and management programme in polytechnics in Nigeria.

Recommendations

Based on the findings of this study, the following recommendations were made:

- NBTE should insist on the appropriate staff and student ratio of 1:30 for quality and effective instructional delivery in office technology and management programme. It should continue to encourage qualified and experienced academic staff for effective teaching and learning in office technology and management programme.

- NBTE should continue to encourage adequacy of physical facilities and equipment in office technology and management programme. Any OTM programme with adequate number of functional facilities and equipment should be asked to provide it for accreditation to be granted.

- There is need for NBTE to pay closer attention to academic content of office technology and management programme through its accreditation exercise. It should be periodically reviewed to ensure currency and consistency with the needs and expectations of industry and society.

- NBTE should put in place effective mechanism for verifying claims made by office technology and management programmes during accreditation. Accreditation visitation should always be accompanied by follow-up or verification visitation.

\section{References}

[1] G. I. Ndinechi, \& G. G. Ado. Self-assessment on word processing and spreadsheet proficiency by office technology and management students in North West Nigerian Polytechnics. Nigerian Journal of Business Education, Vol.1, No. 3, 2014, pp.313-321.

[2] Federal Republic of Nigeria.National Policy on Education. Abuja: NERDC, 2004.

[3] P. Okebukola. Fifty years of higher education in Nigeria: Trends in quality assurance. An Unpublished Conference Paper Presented at International Conference held in University of Illorin, Kwara State from $27^{\text {th }}-29^{\text {th }}$ September, 2010 .

[4] K. Adiagbonya, M. Agbaje \& A. K. Suberu. Quality assurance in business education. Book of Readings in Business Education.Vol. 3, Nol. 1, 2013, pp. 128-134.

[5] N. Azih, (2011). Resource provision for implementation of office technology and management programme in federal polytechnics in the South Eastern States. Delta Journal of Business Education Vol.1 No.6, 2011 pp. 34-43.

[6] A. O. Abimbola. Challenges of using emerging technology in the teaching of office technology and management courses in tertiary institutions in the South-West Nigeria. Nigerian Journal of Business Education Vol.1 No.3, 2014 pp. 46-63.

[7] A. Bature. An investigation into the dynamic roles of secretaries in business organizations.Hassan Usman Katsina Journal of Management Studies, Vol. 2, No. 5, 2008, pp. 1825 . 
[8] C. C. Okolocha \& V. E. Olannye. Supervisors' assessment of computer-based competencies possessed by secretaries in government ministries in Delta State of Nigeria. International Journal of Management Sciences Vol. 5, No. 6, 2015, pp. 467475.

[9] U. A. Ukoha \& C. N. Ahia. Educators' perception of the influence of the National Commission for Colleges of Education accreditation exercise on some quality indicators in NCE vocational teacher training institutions. Journal of Vocational and Adult Education Vol.3 No. 1, 2004, pp. 261-70.

[10] N. V. Okpuzor. Quality assurance in business education:
Gateway to sustainable development. Book of Readings in Business Education, Vol.3 No.1, 2012, pp. 193-198.

[11] S. N. Ohakwe \& S. C Njoku. Curriculum standards, business environment and national development: Tripartite issues in office education. Book of Readings in Business Education, Vol. 1, No. 9, 2009, pp. 74-85.

[12] A. O. Oriazowanlan \& P. L. Umunna. Student industrial work experience scheme: A panacea for promoting students' skill acquisition in business education in tertiary institutions in Edo State. Business Education Journal Vol. 8, No. 2, 2012, pp. 177-188. 